\title{
ATM Gene Deletion
}

National Cancer Institute

\section{Source}

National Cancer Institute. ATM Gene Deletion. NCI Thesaurus. Code C133680.

A molecular abnormality referring to the loss of at least one copy of the ATM gene. 